\title{
Giresun ilinde yetişen yerel bezelye (Pisum sativum L.) populasyonlarının verim ve verim ögelerinin belirlenmesi*
}

\author{
Nuri YILMAZ1 , Havva Vildan KILINÇ² \\ 10rdu Üniversitesi Ziraat Fakültesi Tarla Bitkileri Bölümü, ORDU \\ ${ }^{2}$ Gıda Tarım ve Hayvancılık Bakanlığı, Altınordu İlçe Gıda Tarım ve Hayvancılık Müdürlüğü ORDU \\ *İkinci yazarın yüksek lisans çalışmasından alınmıştır.
}

Alınış tarihi: 18 Ocak 2018, Kabul tarihi: 10 Nisan 2018

Sorumlu yazar: Nuri YILMAZ, e-posta:y_nuri@hotmail.com

$\ddot{0} \mathbf{z}$

Bu çalışma 2012-2013 yetiştirme döneminde Giresun ilinde yetişen yerel bezelye genotiplerinin verim ve verim ögelerinin belirlenmesi amacıyla Ordu Üniversitesi Ziraat Fakültesi deneme arazisinde kurulmuştur. Giresun ili farklı ilçeleri 2012 yılı Eylül ve Ekim aylarında gezilerek, tane tüketim amaciyla yetiștirilen bezelye genotiplerinin tohumları yerel pazarlardan toplanmıştır. Deneme materyali 24 adet genotip ile kontrol olarak değerlendirilen 3 adet ticari çeşitten oluşmaktadır. Augmented deneme desenine göre planlanan denemede Ekim ve Kasım tarihinde, sıra arası $40 \mathrm{~cm}$, sıra üzeri $10 \mathrm{~cm}$, siraların uzunluğu $4 \mathrm{~m}$ ve her genotip 2 sira olacak şekilde tesis edilmiștir. Bitkiler kuru hasat olgunluğu dönemine geldiklerinde elle hasat edilmiștir. Çalıșma sonunda bitkide bakla sayısı 9.70-29.85 adet/bitki, baklada tane sayısı 4.95-8.15 adet/bakla, bitkide tane verimi $18.45-28.69 \mathrm{~g} /$ bitki, bakladaki ortalama kuru tanelerin ağırlığı 0.90-2.71 g, dekara tane verimi 92.25-143.45 kg/da, dekara biyolojik verim $156.03-250.43 \mathrm{~kg} / \mathrm{da}$, bin tane ağırlığı 128.39-243.82 $\mathrm{g}$, hasat indeksi \% 53.00-73.00 ve protein oranı \% 19.86-28.12 olarak hesaplanmıştır.

Anahtar kelimeler: Bezelye, Pisum sativum L., genotip, verim, verim ögeleri
Determination of yield and yield components of local peas (Pisum sativum L.) types grow the provice in Giresun

\begin{abstract}
This study was conducted in research area of Agriculture Faculty at University of Ordu, during the 2012-2013 to determination of yield and yield component of local peas types grow the provice in Giresun. Different towns of Giresun province were visited in September and October 2012 and the seeds of pea genotypes grown for grain consumption were collected from local bazaar. The experiment materials consists of 3 commercial varieties which are evaluated as control with 24 genotypes. According to the Augmented trial design, sowing was carried out on 20 November with $40 \mathrm{~cm}$ between rows, $10 \mathrm{~cm}$ over rows, $4 \mathrm{~m}$ lengths and 2 rows for each genotype. The plants were harvested by hand when they reached the dry harvest maturity period. As a result of study; number of pods per plant 9.7-29.85 pcs/plant, number of grains per pod 4.95-8.15 pcs/pods, grain per plant $18.45-28.69 \mathrm{~g} /$ plant, the average weight of one dry pods $0.90-2.71 \mathrm{~g}$, grain yield per unit of area $92.25-143.45 \mathrm{~kg} / \mathrm{da}$, biological yield per unit of area $156.03-250.43 \mathrm{~kg} / \mathrm{da}, 1000$ seed weight 128.39-243.82 g, harvest index \% 53.0073.00 and protein contetnt \% 19.86 -28.12 respectivey.
\end{abstract}

Key words: Peas, Pisum sativum L., genotype, yield, yield component 


\section{Giriş}

Ülkemiz tarım alanlarının \%10'unu kapsayan yemeklik tane baklagil bitkileri, gerek sahip oldukları yüksek protein içeriği nedeniyle beslenme ve gerekse azot bağlama özelliklerinden dolayı ekim nöbeti sistemlerinde aranan bitkilerdir. Yemeklik tane baklagiller binlerce yıldır insanların diyetlerinin önemli bir kısmını oluşturmuştur. Yararlanma ve kullanım şekillerine göre özellikle proteince zengin bitkilerdir. İnsan beslenmesinde hayvansal proteinler, bitkisel proteinlerden daha uygun olmasına rağmen gerekli olan hayvansal proteinin sağlanamadığ yerlerde besinleri biyolojik olarak tamamlayacak besinlere gereksinim vardır. Yemeklik tane baklagiller bu yönden çok uygundurlar.

Yemeklik tane baklagillerden biri olan bezelye, dünyanın pek çok ülkesinde yıl boyunca en fazla tüketilen baklagil olmasına karşın, ülkemizde tüketme alışkanlığının yaygın olmaması nedeniyle ekim alanı ve üretim yönünden henüz beklenen düzeye ulaşılamamıştır. Genelde taze baklaları veya kuru taneleri için yetiştirilen bezelyenin ekiliş ve üretiminde, son yıllarda konserve ve dondurulmuş gida sanayinin hızla gelişmesi önemli artışlar sağlamıştır (Öz ve Karasu, 2010).

İklim ve toprak istekleri göz önüne alındığında, dünyada geniş ekolojik alanlarda ve ülkemizin hemen her yerinde yetiştirilebilme özelliğine sahip olan bezelye, llıman iklim bitkisi olmakla beraber genellikle serin iklimin hâkim olduğu tınlı-kumlu topraklarda daha iyi bir gelişme gösterir (Ceyhan ve Mülayim, 2003). Serin iklim baklagilleri arasında yer alan bezelye, düşük sıcaklıklara dayanabilen, nemli ve serin iklimden hoşlanan bir baklagil bitkisi olması nedeniyle ülkemizde önemli bir potansiyele sahiptir.

Ekim alanındaki azlığa paralel olarak, ülkemizde tarımı yapılan yemeklik baklagil türleri içerisinde bezelye, yerli tescilli çeşit sayısı bakımından en fakir olanıdır. Ülkemizde kuru tane amaçlı kullanıma yönelik hiçbir tescilli çeşit yokken, taze tüketim amaçlı bugüne kadar 43 adet çeşit, tescilli veya üretim izinli olarak piyasada yer almıştır. Bunlardan da sadece bir tanesi ülkemizde tescil edilmiştir. Oysa ülkemizin içinde bulunduğu Yakın Asya ve Akdeniz gen merkezleri birçok bitki için olduğu gibi bezelyenin de gen merkezidir. Bu materyallerin ve bitkisel çeşitliliğin günümüzden geleceğe aktarılması korunması, saklanması ve değerlendirilmesi tarımın sürdürülebilirliği için en önemli kaynaklardır.
Yetiştikleri bölgelerin ekolojik koşullarına tam olarak uyum sağlayan genetik materyal tarımın dolaylsıyla insanlığın geleceğinin güvencesidir (Özgen ve ark., 2000). Bitki ıslahı çalışmalarının esasını genetik kaynaklardaki çeşitlilik oluşturmaktadır. Primitif formlar ve yerel çeşitler genetik taban olarak kültür bitkilerinin ileride çıkabilecek sorunlarının giderilmesinde veya kültür bitkilerine yeni özelliklerin aktarılmasında önemli genetik kaynaklardır (Akgün ve ark., 1998). Türkiye gerek coğrafik yapısı gerekse sahip olduğu değişik ekolojik koşullar nedeniyle bitkisel gen kaynakları bakımından dünyada çok önemli bir konuma sahiptir (Özgen ve ark., 2000). Yaygın olarak tarımı yapılan 6 yemeklik tane baklagil türünden 4'ünün anavatanıdır.

Karadeniz bölgesinin kıyı kesimleri, bezelyenin ekolojik isteklerine uygundur. Bölgede bezelye kışlık olarak yetiştirilebilmekte, taze olarak erken dönemde pazara sunulabilmekte ve peşi sıra yazlık bir ürünün ekilebilmesine imkan vermektedir. Ancak bölgede bezelye ekim alanları istatistiklere girmeyecek kadar azdır. Bölgede genellikle bezelye tarımı aile ihtiyacına yönelik olarak yapılmaktadır. Bezelyenin tarımını geliştirmeye yönelik çalışmaların arttırılmasında fayda vardır. Bu çalışmaların başında, bölgeye uygun çeşitlerin geliştirilmesi gelmektedir (Karayel ve Bozoğlu, 2008).

Ülkemiz ve bölgemiz genetik kaynak çeşitleri bakımdan oldukça zengindir. Bir ülkenin sahip olduğu yabani bitki formları ve yerel köy çeşitleri mevcut kültür bitkilerinin özelliklerinin iyileștirilmesi veya yeni çeşitlerin bulunması için gerekli gen depolarıdır. Bitkisel üretimde devamlılık ancak bu materyallerin korunmasıyla mümkün olacaktır. Bu nedenle zengin bir çeşitliliğe sahip olan ülkemizin bu kaynaklarını koruması sürdürülebilir tarım ve yaşam için mutlak bir gerekliliktir. Doğu Karadeniz Bölgesi yöre şartlarına uyum sağlamış çok sayıda mahalli bezelye tipi ile büyük bir popülasyon zenginliğine sahiptir. Şu ana kadar Giresun ilinde bezelye gen kaynaklarının değerlendirilmesine yönelik geniş çaplı bir araştırma yapılmamıştır. Bu çalışma ile Giresun ili taranarak yörede yetiştirilen çevre koşullarına uyum sağlamış bezelye popülasyonları toplanarak, verim ve verim ögeleri incelenerek kayıt altına alınmıştır.

$\mathrm{Bu}$ çalışmada amacımız; Giresun ilinden toplanan yerel bezelye genotiplerine ait tanımlayıcı bilgilerin kayıt altına alınması, verim ve verim ögelerinin 
belirlenmesi ve yüksek verimli genotipler tespit edilerek bundan sonraki ıslah ve çeşit geliştirme konusunda yapılacak çalışmalara yararlı olabilecek alt yapı sağlayacak olmasıdır.

\section{Materyal ve Yöntem}

\section{Materyal}

Deneme, Ordu şehir merkezine yaklaşık $5 \mathrm{~km}$ mesafedeki Ordu Üniversitesi Ziraat Fakültesi uygulama alanında yürütülmüştür. Deneme alanının toprak tekstürü tınlı yapıda, Nötr reaksiyon ( $\mathrm{pH}=7,52)$ özelliğindedir. Potasyum miktarı yüksek (43 kg/da $\left.\mathrm{K}_{2} \mathrm{O}\right)$, organik madde $(\% 0.56)$ ve fosfor miktarı (5.58 $\mathrm{kg} / \mathrm{da}$ ) azdır (Anonim, 2012).

Ordu ilinde kıyıya paralel olarak uzanan dağlar nedeniyle, ilde kıyı kesimde ve iç kesimde farklı iklim yaşanmaktadır. Denemenin yürütüldüğü kıyı kesimde kışlar ılıman, yazlar nispeten serin ve her mevsim yağışlı geçmektedir.

Denemenin yürütüldüğü 2012-2013 vejetasyon döneminde en düşük ortalama sıcaklık $9.4^{\circ} \mathrm{C}$ ile Ocak ayında, en yüksek ortalama sıcaklık ise $17.9^{\circ} \mathrm{C}$ ile Mayıs ayında gözlenmiştir. Bu döneme ait ortalama sıcaklık ise $12.5^{\circ} \mathrm{C}$ olarak kaydedilmiştir (Anonim, 2013).

Denemenin yürütüldüğü 2012-2013 yetiştirme sezonunda, toplam $643.8 \mathrm{~mm}$ yağış düşmüş ve en düşük yağış 21.9 mm ile Nisan ayında, en yüksek yağış 201.3 mm ile Kasım ayında gerçekleşmiştir. Denemenin yürütüldüğü dönemde en düșük nem \% 63.7 ile Ocak ayında en yüksek nem \% 74.2 ile Kasım ayında kaydedilmiştir (Anonim, 2013). Ordu ilinin iklim verileri bezelye yetiştiriciliği açısından uygun bir ekolojiye sahip olduğu görülmektedir.

Araştırma kapsamındaki Giresun ilinin Eynesil, Görele, Tirebolu, Çanakçı, Dereli, Espiye, Keșap, Bulancak, Piraziz, Yağlıdere ve Güce ilçeleri 2012 yılı EylülEkim aylarında gezilerek, tane tüketim amacıyla yetiştirilen bezelye genotiplerinin tohumları yerel pazarlar dolaşılarak materyal olarak toplanmıştır. Toplanan materyaller 24 adet genotip ile kontrol olarak değerlendirilen 3 adet ticari çeşitten oluşmaktadır. Toplanan genotiplerin ve ticari çeşitlerin kayıt numaraları ve geldiği yerlerin adları Çizelge 1'de gösterilmiştir.

Toplanan bu genotiplerin tohumları ile Geçit Kuşağı Tarımsal Araştırma Enstitüsü ve May Tohumculuk Ziraat ve Ticaret Ltd. Şti'den temin edilen sertifikalı tohumlar (Bolero, Utrilla, Sprinter) 2012 yılı Kasım ayında tarla denemelerine alınmıştır.
Çizelge 1. Bezelye genotiplerinin ve ticari çeşitlerin numaraları ve toplandığı yerlerin adı

\begin{tabular}{cccc}
\hline Genotip & Kod & İlçe & Köy \\
\hline G1 & TR2801 & Eynesil & Ören \\
G2 & TR2802 & Eynesil & Kekiktepe \\
G3 & TR2803 & Görele & Daylı \\
G4 & TR2804 & Görele & Terziali \\
G5 & TR2805 & Görele & Aralıkoz \\
G6 & TR2806 & Görele & Doğankent \\
G7 & TR2807 & Tirebolu & Işıklı \\
G8 & TR2808 & Tirebolu & Sultanköy \\
G9 & TR2809 & Tirebolu & Halaçlı \\
G10 & TR2810 & Çanakçı & Akköy \\
G11 & TR2811 & Çanakçı & Egeköy \\
G12 & TR2812 & Dereli & Sarıyer \\
G13 & TR2813 & Dereli & Sütlüce \\
G14 & TR2814 & Espiye & Çepni \\
G15 & TR2815 & Espiye & Bahçecik \\
G16 & TR2816 & Keşap & Töngel \\
G17 & TR2817 & Keşap & Tepeköy \\
G18 & TR2818 & Bulancak & Esenköy \\
G19 & TR2819 & Bulancak & Güneyköy \\
G20 & TR2820 & Piraziz & Narlık \\
G21 & TR2821 & Yağlıdere & Hisarcık \\
G22 & TR2822 & Güce & Fındıklı \\
G23 & TR2823 & Doğankent & Güdül \\
G24 & TR2824 & Doğankent & Çatak \\
\hline & & Bolero & \\
& & Utrilla & \\
\hline
\end{tabular}

\section{Yöntem}

Deneme 20 Kasım 2012 tarihinde kurulmuştur. Denemeye alınan genotiplerin tohumları sıra arası 40 $\mathrm{cm}$, sıra üzeri $10 \mathrm{~cm}$, sıraların uzunluğu $4 \mathrm{~m}$ ve her genotip 2 sira olacak şekilde Augmented Deneme Desenine göre kurulmuştur. Parsel alanı $0.4 \times 0.1 \times 4 \times 2=3,2 \mathrm{~m}^{2}$ olup her parselde 40 bitki olması amaçlanarak açılan karıklara 2'şer tohum bırakılmış, çıkıştan sonra tekleme işlemi yapılmıştır. Toplam 24 genotip ve 3 ticari çeşitin olduğu deneme alanımız $172.8 \mathrm{~m}^{2}$ dir. Deneme alanına ekim öncesi toprak işleme sırasında Azot 3-4 kg/da, Fosfor( $\left.\mathrm{P}_{2} \mathrm{O}_{5}\right)$ 8-10 kg/da, Potasyum( $\left.\mathrm{K}_{2} \mathrm{O}\right) 20 \mathrm{~kg} /$ da gübreleri verilmiştir (Anonim, 2006). Yabancı ot mücadelesi çapa ile yapılmıştır. Kışlık ekim yapıldığından sulama yapılmamıştır. Bitkiler kuru hasat olgunluğu dönemine geldiklerinde elle ve yolunarak hasat edilmiştir. Hasat esnasında parsel başlarından ve sonlarından $0.5 \mathrm{~cm}$ kenar tesiri bırakılmıştır. Yürütülecek tarla denemelerinde, ekilen genotiplerde çıkıştan hasada kadarki dönemde Salk, (1971), Gülümser (1981), Özalp (1993), Demirci ve Ünver, (1997) ve Akçin (1974) gibi çeşitli araştırıcıların ve Gıda Tarım ve Hayvancılık Bakanlığı Tohumluk Tescil ve Sertifikasyon Merkezi Müdürlüğünün Tarımsal Değerleri Ölçme Denemeleri Teknik Talimatı'nın (Anonim, 2001) belirttiği şekilde Bitkide Bakla Sayısı (adet/bitki), 
Baklada Tane Sayısı (adet/bakla), Bakladaki Ortalama Kuru Tanelerin Ağırlı̆̆ (gr), Bitkide Tane Verimi (gr/bitki), Bin Tane Ağırlığı (gr), Dekara Tane Verimi (kg/da), Dekara Biyolojik Verim (kg/da), Hasat İndeksi (\%), Protein Oranı (\%) gibi verim ve verim öğelerine ait ölçümler yapılmıştır. Temel istatistikler (ortalama, standart hata ve \% C.V. gibi değerler) için SPSS 15.0 paket programı, kullanılmıștır (SPSS, 2006).

\section{Bulgular ve Tartışma}

\section{Bitkide bakla sayısı}

Denemeye alınan bezelye çeşit ve genotiplerinin bakla sayısına (adet/bitki) ait ortalama, standart hata ve varyasyon katsayısı değerleri Çizelge 2'de verilmiştir. Ticari çeşitlerde bitkide bakla sayısı 9.7017.45 adet/bitki arasında değişim göstermiștir. Çeşitlerde bakla sayısı en yüksek 17.45 adet/bitki ile Utrilla çeşidinden, en düşük ise 9.70 adet/bitki ile Sprinter çeşidinden tespit edilmiştir. Bezelye genotiplerinde ise bitkide bakla sayısı 9.70-29.85 adet/bitki arasında değişim göstermiştir. Genotip- lerden G3 genotipinde 29.85 adet/bitki ile bakla sayısının en yüksek olduğu, G8 genotipinde ise 9.70 adet/bitki bakla sayısı en düşük olduğu bulunmuştur. Genotiplerin varyasyon katsayıları incelendiğinde G20 genotipi \%29,21 ortalaması ile en yüksek, G3 genotipi ise \%12.06 ortalaması ile en düşük varyasyon katsayısına sahip olduğu bulunmuştur. Konuyla ilgili çalışma yapan araştırmacılardan; Pekşen ve ark., (2004), 15.44 adet, Bozoğlu ve ark., (2004), 12.62 adet/bitki, Gülümser ve ark., (1994), 10 ile 16.3 adet, Qasim ve ark., (2001), 36 ile 60 adet, Seyis, (1994), 4.20 ile 8.80 adet olarak bildirmişlerdir. Değerler karşılaștırıldığında Pekșen ve ark., (2004), Bozoğlu ve ark., (2004), ve Gülümser ve ark., (1994), belirttiği değerlerle uyum halinde olduğu görülmektedir. Qasim ve ark., (2001), ve Seyis, (1994), belirttiği değerlerle uyum sağlamamaktadır. Farklılığın genetik ve ekolojik şartlardan kaynaklandığı düşünülmektedir. Tane sayısıyla verim doğru orantılı olduğundan tane sayısı arttıkça verim yükselmektedir. Bizim çalışmamızda da bitkide bakla sayısı arttıkça bitki başına verim artış göstermektedir.

Çizelge 2. Bezelye çeşit ve genotiplerine ait bitkide bakla sayısı (adet/bitki) ve baklada tane(adet/bitki) sayısına ilişkin ortalama, standart hata ve varyasyon katsayısı değerleri

\begin{tabular}{|c|c|c|c|c|c|}
\hline \multirow{2}{*}{ Genotip } & \multirow{2}{*}{ Kod } & \multicolumn{2}{|c|}{ Bitkide bakla sayısı } & \multicolumn{2}{|c|}{ Baklada tane sayısı } \\
\hline & & Ort. \pm Std.Hata & C.V. $(\%)$ & Ort. \pm Std.Hata & C.V. $(\%)$ \\
\hline G1 & TR2801 & $12.95 \pm 0.621$ & 21.47 & $7.40 \pm 0.386$ & 23.36 \\
\hline G2 & TR2802 & $11.80 \pm 0.734$ & 27.85 & $8.15 \pm 0.334$ & 18.36 \\
\hline G3 & TR2803 & $29.85 \pm 0.805$ & 12.06 & $7.75 \pm 0.279$ & 16.14 \\
\hline G4 & TR2804 & $20.25 \pm 0.668$ & 14.76 & $4.95 \pm 0.211$ & 19.08 \\
\hline G5 & TR2805 & $19.95 \pm 1.022$ & 22.91 & $6.80 \pm 0.224$ & 14.78 \\
\hline G6 & TR2806 & $20.65 \pm 1.071$ & 23.21 & $7.45 \pm 0.245$ & 14.75 \\
\hline G7 & TR2807 & $16.40 \pm 0.488$ & 13.32 & $7.00 \pm 0.271$ & 17.34 \\
\hline G8 & TR2808 & $9.70 \pm 0.363$ & 16.75 & $5.90 \pm 0.190$ & 14.44 \\
\hline G9 & TR2809 & $17.70 \pm 0.778$ & 19.66 & $6.80 \pm 0.267$ & 17.59 \\
\hline G10 & TR2810 & $11.25 \pm 0.458$ & 18.21 & $6.20 \pm 0.247$ & 17.82 \\
\hline G11 & TR2811 & $20.65 \pm 0.990$ & 21.44 & $6.70 \pm 0.218$ & 14.60 \\
\hline G12 & TR2812 & $20.60 \pm 0.744$ & 16.16 & $6.65 \pm 0.208$ & 14.03 \\
\hline G13 & TR2813 & $18.75 \pm 1.222$ & 29.15 & $7.15 \pm 0.166$ & 10.42 \\
\hline G14 & TR2814 & $26.60 \pm 0.966$ & 16.24 & $7.05 \pm 0.184$ & 11.71 \\
\hline G15 & TR2815 & $13.75 \pm 0.428$ & 13.93 & $6.80 \pm 0.186$ & 12.25 \\
\hline G16 & TR2816 & $19.45 \pm 0.573$ & 13.18 & $7.00 \pm 0.177$ & 11.35 \\
\hline G17 & TR2817 & $14.70 \pm 0.607$ & 18.47 & $6.80 \pm 0.212$ & 13.99 \\
\hline G18 & TR2818 & $10.40 \pm 0.494$ & 21.25 & $6.15 \pm 0.254$ & 18.48 \\
\hline G19 & TR2819 & $16.40 \pm 0.841$ & 22.93 & $6.60 \pm 0.222$ & 15.07 \\
\hline G20 & TR2820 & $14.80 \pm 0.966$ & 29.21 & $6.60 \pm 0.210$ & 6.35 \\
\hline G21 & TR2821 & $16.80 \pm 0.467$ & 12.45 & $6.50 \pm 0.211$ & 14.55 \\
\hline G22 & TR2822 & $14.20 \pm 0.724$ & 22.80 & $5.95 \pm 0.266$ & 20.01 \\
\hline G23 & TR2823 & $13.00 \pm 0.542$ & 18.67 & $6.75 \pm 0.203$ & 13.48 \\
\hline $\mathrm{G} 24$ & TR2824 & $20.55 \pm 0.881$ & 19.17 & $6.75 \pm 0.227$ & 15.10 \\
\hline Genotip ort. & & $17.13 \pm 0.727$ & 19.39 & $6.74 \pm 0.233$ & 15.21 \\
\hline Bolero & & $15.65 \pm 0.932$ & 26.65 & $7.15 \pm 0.195$ & 12.23 \\
\hline Utrilla & & $17.45 \pm 0.990$ & 25.38 & $7.20 \pm 0.171$ & 10.66 \\
\hline Sprinter & & $9.70 \pm 0.363$ & 16.75 & $5.90 \pm 0.190$ & 14.44 \\
\hline Çeşit ort. & & $14.26 \pm 0.761$ & 22.92 & $6.75 \pm 0.185$ & 12.44 \\
\hline Genel ort. & & $15.69 \pm 0.744$ & 21.15 & $6.74 \pm 0.209$ & 13.82 \\
\hline
\end{tabular}




\section{Baklada tane sayısı}

Denemeye alınan bezelye çeşit ve genotiplerinin baklada tane sayısına (adet/bitki) ait ortalama, standart hata ve varyasyon katsayısı değerleri Çizelge 2' de verilmiștir.

Çizelge 2 incelendiğinde ticari çeşitlerde baklada tane sayısı 5.90-7.20 adet/bakla arasında değişim gösterdiği görülmektedir. Ticari çeşitlerden Utrilla çeşidinde 7.20 adet/bakla ile baklada tane sayısının en yüksek, Sprinter çeşidin de ise 5.90 adet/bakla ile tane sayısının en düşük olduğu bulunmuştur. Bezelye genotiplerinde ise baklada tane sayısı 4.95-8.15 adet/bakla arasında değişim göstermiştir. Genotiplerden G2 genotipi 8.15 adet/bakla ile baklada tane sayısının en yüksek olduğu, G4 genotipinin ise 4.95 adet/bakla ile baklada tane sayısının en düşük olduğu bulunmuștur. Genotiplerin varyasyon katsayıları incelendiğinde G1 genotipi \%23.36 ortalaması ile en yüksek, G20 genotipi ise \%6.35 ortalaması ile en düşük varyasyon katsayısına sahip olduğu bulunmuştur. Konuyla ilgili yapılan çalışmalarda araştırmacılardan; baklada tane sayısını Acar ve Ayan, (2000), 1 ila10 adet/bakla, Anlarsal ve ark., (2001), 3.98 adet/bakla, Qasim ve ark., (2001), 8.5 adet/bakla, Gülümser ve ark., (1994), 4.0 ile 6.9 adet/bakla, Sincik ve ark., (1997), 5.80 adet/bakla, Bozoğlu ve ark., (2004), 6.11 adet/bakla olarak bildirmişlerdir. Tespit edilen değerlerle çalışmamızda bulduğumuz değerler uyum sağlamaktadır. Baklada tane sayısı, verimi etkileyen önemli verim unsurlarından birisidir. Özellikle taze tüketimlerde de dikkate alınan ve tanenin büyüklüğüne etki eden önemli agronomik özelliklerdendir.

\section{Bitkide tane verimi}

Denemeye alınan bezelye çeșit ve genotiplerinin bitkide tane verimine (g/bitki) ait değerler Çizelge 3 . de verilmiştir. Çizelge 3. Görüldüğü gibi ticari çeşitlerde bitkide tane verimi 25.35-27.94 g/bitki arasında değişim göstermiştir. Utrilla çeșidinde 27.94 $\mathrm{g} /$ bitki ile tane verimi en yüksek, Bolero çeșidinde ise $25.35 \mathrm{~g} /$ bitki ile tane verimi en düșük olduğu bulunmuştur. Bezelye genotipleri incelendiğinde tane verimi 18.45-28.69 g/bitki arasında değişim göstermiştir. Genotiplerden G16 genotipi 28.69 $\mathrm{g} /$ bitki ile tane verimi en yüksek, G10 genotipi ise $18.45 \mathrm{~g} /$ bitki ile tane verimi en düşük olduğu bulunmuştur. Konuyla ilgili çalışma yapan araştırmacılardan; Koivisto ve ark., (2002), 8.95 g/bitki, Kara ve Ünver, (2000), 6.56 g/bitki, Açlkgöz ve Uzun, (1997), 9.7 ile 35.2 g/bitki, Karayel, (2006), 5.3 ile 30.0 g/bitki ve Anlarsal ve ark., (2001), 23.7 g/bitki olarak belirlemişlerdir. Bulduğumuz değerler Karayel, (2006), ve Anlarsal ve ark., (2001), çalışmalarında tespit ettikleri değerlerle uyum sağlamaktadır.

Bitkide tane sayısı ve baklada tane sayısı bitki bașına verimi etkileyen önemli değerlerdir. Verimli bir yetiştiricilikte bu değerlerin yüksek olması istenmektedir. Islah çalışmalarında bitkide tane veriminin arttırılması amaçlanmaktadır. Bu bakımdan çalışmamızdaki genotiplerden G16 genotipi tane verimi olarak ticari çeşitlerden daha yüksek verime sahiptir.

Çizelge 3. Bezelye çeşit ve genotiplerinin bitkide tane verimi (gr/bitki) ve bakladaki ortalama kuru tanelerin ağırlı̆̆ına (gr) ait değerler

\begin{tabular}{|c|c|c|c|}
\hline Genotip & Kod & $\begin{array}{c}\text { B. T. V. } \\
\text { (gr/bitki) }\end{array}$ & $\begin{array}{l}\text { B. K. T. A. } \\
\text { (gr) }\end{array}$ \\
\hline G1 & TR2801 & 28.55 & 2.20 \\
\hline G2 & TR2802 & 25.45 & 2.15 \\
\hline G3 & TR2803 & 27.00 & 0.90 \\
\hline G4 & TR2804 & 19.07 & 0.94 \\
\hline G5 & TR2805 & 26.66 & 1.33 \\
\hline G6 & TR2806 & 23.56 & 1.14 \\
\hline G7 & TR2807 & 26.78 & 1.63 \\
\hline G8 & TR2808 & 25.36 & 2.61 \\
\hline G9 & TR2809 & 26.53 & 1.49 \\
\hline G10 & TR2810 & 18.45 & 1.64 \\
\hline G11 & TR2811 & 27.86 & 1.34 \\
\hline G12 & TR2812 & 19.66 & 0.95 \\
\hline G13 & TR2813 & 25.47 & 1.35 \\
\hline G14 & TR2814 & 26.27 & 0.98 \\
\hline G15 & TR2815 & 28.25 & 2.05 \\
\hline G16 & TR2816 & 28.69 & 1.47 \\
\hline G17 & TR2817 & 26.38 & 1.79 \\
\hline G18 & TR2818 & 28.27 & 2.71 \\
\hline G19 & TR2819 & 25.75 & 1.57 \\
\hline G20 & TR2820 & 26.59 & 1.79 \\
\hline G21 & TR2821 & 27.37 & 1.62 \\
\hline G22 & TR2822 & 23.31 & 1.64 \\
\hline G23 & TR2823 & 24.48 & 1.88 \\
\hline G24 & TR2824 & 27.34 & 1.33 \\
\hline Genotip ort. & & 25.55 & 1.60 \\
\hline Bolero & & 25.35 & 1.61 \\
\hline Utrilla & & 27.94 & 1.60 \\
\hline Sprinter & & 26.35 & 1.56 \\
\hline Çeşit ort. & & 26.55 & 1.59 \\
\hline Genel ort. & & 26.05 & 1.59 \\
\hline
\end{tabular}

\section{Bakladaki ortalama kuru tanelerin ağırlığı}

Denemeye alınan bezelye çeșit ve genotiplerinin bakladaki ortalama kuru tanelerin ağırlığı (gr) ait değerler Çizelge 3'de verilmiştir. Çizelge 3 incelendiğinde ticari çeşitlerde bakladaki kuru tanelerin ağırlığı 1.56-1.61 g arasında değiștiği görülmektedir. Bolero çeşidi $1.61 \mathrm{~g}$ ile baklada kuru tane ağırlığı en yüksek, Sprinter çeşidi ise 1.56 g ile kuru tane ağırlığı en düşük olduğu bulunmuştur. Bezelye genotiplerinde ise bakladaki kuru tanelerin ağırlığı 0.90-2.71 g arasında değişim göstermiştir. 
Genotiplerden G18 genotipi 2.71 g ile kuru tane ağllığı en yüksek, G3 genotipi ise 0.90 g ile kuru tane ağırlığı en düşük olduğu bulunmuştur.

Konuyla ilgili çalışma yapan araştırmacılardan; Vural, (1971), 0.75 ile1.03 g ve Girgel, (2006), 0.828 g olarak bildirmişlerdir. Tespit edilen değerlerle bulduğumuz değerleri karşılaştırdığımızda çalışmamızdaki değerlerin biraz daha yüksek olduğu görülmektedir. Bunun sebebinin genetik faktörler, yetiștirme teknikleri ve toprak yapısından kaynaklandığı sanılmaktadır.

\section{Dekara tane verimi}

Denemeye alınan bezelye çeşit ve genotiplerinin dekara tane verimine (kg/da) ait değerler Çizelge 4. de verilmiștir.

Çizelge 4. incelendiğinde ticari çeşitlerde dekara tane verimi $126.7-139.7 \mathrm{~kg} /$ da arasında değişim göstermiştir. Çeşitlerden Utrilla $139.7 \mathrm{~kg} /$ da ile tane verimi en yüksek, Bolero çeşidi ise $126.7 \mathrm{~kg} / \mathrm{da}$ ile tane verimi en düşük olduğu bulunmuştur. Bezelye genotiplerinde ise tane verimi 92.2-143.4 kg/da arasında değişim göstermiştir. Genotiplerden G16 genotipi $143.4 \mathrm{~kg} /$ da ile tane verimi en yüksek, G10 genotipi ise $92.2 \mathrm{~kg} / \mathrm{da}$ ile tane verimi en düşük olduğu bulunmuştur.

Konuyla ilgili çalışma yapan araştırmacılardan; Gülümser, (1978), 112.6 ile $192.1 \mathrm{~kg} / \mathrm{da}$, Kaya, (2000), 63.5 ile $223.8 \mathrm{~kg} / \mathrm{da}$, McPhee ve Muehlbauer, (2002), 128.0 ile $309.0 \mathrm{~kg} / \mathrm{da}$, Ceyhan ve Önder, (2001), 111.6 ile $160.9 \mathrm{~kg} /$ da ve Ceyhan ve Avcl, (2007), 72.0 ile $143.3 \mathrm{~kg} /$ da olarak bildirmişlerdir. Tespit edilen değerlerle çalışmamızda bulduğumuz değerler uyum sağlamaktadır.

$\mathrm{Bu}$ sonuçlar bize farklı çevre ve genotipler ile bunların etkileşimlerinin tane verimini etkilediğini göstermektedir. Uygulanan kültürel işlemlerle tane verimi arttırılabilmektedir. Çalışmamızdaki genotiplerden G16 genotipi ticari çeşitlerden daha yüksek tane verimine sahiptir. Bezelye yetiştiriciliğinde dekara tane veriminin yüksek olması aranılan bir özelliktir.

\section{Dekara biyolojik verim}

Denemeye alınan bezelye çeşit ve genotiplerinin dekara biyolojik verimine $(\mathrm{kg} / \mathrm{da})$ ait değerler Çizelge 4 . de verilmiştir. Çizelge 4 incelendiğinde ticari çeşitlerde biyolojik verimi 191.3-73.6 kg/da arasında değișim göstermiștir. Çeşitlerden Utrilla 191.3 $\mathrm{kg} /$ da ile biyolojik verimi en yüksek, Bolero çeşidi ise $173.6 \mathrm{~kg} / \mathrm{da}$ ile biyolojik verimi en düşük olduğu bulunmuştur. Bezelye genotiplerinde ise biyolojik verimi $156.0-250.4 \mathrm{~kg} / \mathrm{da}$ arasında değişmiştir. Genotiplerden G1 genotipi $250.4 \mathrm{~kg} / \mathrm{da}$ ile biyolojik verimi en yüksek, G12 genotipi ise $156.0 \mathrm{~kg} / \mathrm{da}$ ile biyolojik verimi en düşük olduğu bulunmuştur.

Çizelge 4. Bezelye çeşit ve genotiplerinin dekara tane verimi $(\mathrm{kg} / \mathrm{da})$ ve biyolojik verime $(\mathrm{kg} / \mathrm{da})$ ait değerler

\begin{tabular}{cccc}
\hline Genotip & Kod & $\begin{array}{c}\text { D. T. V. } \\
(\mathrm{kg} / \mathrm{da})\end{array}$ & $\begin{array}{c}\text { D.B.V. } \\
\text { (kg/da) }\end{array}$ \\
\hline G1 & TR2801 & 142.7 & 250.4 \\
G2 & TR2802 & 127.2 & 212.0 \\
G3 & TR2803 & 135.0 & 217.7 \\
G4 & TR2804 & 95.3 & 161.6 \\
G5 & TR2805 & 133.3 & 215.0 \\
G6 & TR2806 & 117.8 & 184.0 \\
G7 & TR2807 & 133.9 & 226.9 \\
G8 & TR2808 & 126.8 & 222.4 \\
G9 & TR2809 & 132.6 & 213.9 \\
G10 & TR2810 & 92.2 & 174.0 \\
G11 & TR2811 & 139.3 & 236.1 \\
G12 & TR2812 & 98.3 & 156.0 \\
G13 & TR2813 & 127.3 & 219.5 \\
G14 & TR2814 & 131.3 & 202.0 \\
G15 & TR2815 & 141.2 & 196.1 \\
G16 & TR2816 & 143.4 & 202.0 \\
G17 & TR2817 & 131.9 & 193.9 \\
G18 & TR2818 & 141.3 & 193.6 \\
G19 & TR2819 & 128.7 & 195.0 \\
G20 & TR2820 & 132.9 & 237.4 \\
G21 & TR2821 & 136.8 & 235.9 \\
G22 & TR2822 & 116.5 & 204.4 \\
G23 & TR2823 & 122.4 & 204.0 \\
G24 & TR2824 & 136.7 & 201.0 \\
\hline Genotip ort. & & 127.7 & 206.45 \\
\hline Bolero & & 126.7 & 173.6 \\
Utrilla & & 139.7 & 191.3 \\
\hline Çeşit ort. & & 131.7 & 185.5 \\
\hline Genel ort. & & 130.2 & 194.92 \\
\hline & & & \\
\hline
\end{tabular}

Konuyla ilgili çalışma yapan araştırmacılardan; Gülümser, (1978), 234.5 ile 352.4 kg/da, Özalp, (1993), 209.3 ile $251.8 \mathrm{~kg} / \mathrm{da}$ ve Ceyhan ve ark., (2005), 461.2 ile $762.0 \mathrm{~kg} / \mathrm{da}$ olarak bildirmişlerdir. Tespit edilen değerlerle çalışmamızda bulduğumuz değerler uyum içerisindedir. Bazı litaratür değerleriyle uyum sağlamamaktadır. Bunun sebebinin genetik faktörler ve ekolojik şartlardan kaynaklandığı sanılmaktadır.

\section{Bin tane ağırlığı}

Denemeye alınan bezelye çeşit ve genotiplerinin bin tane ağırlığ 1 (g) ait değerler Çizelge 5. de verilmiştir.

Çizelge 5. incelendiğinde ticari çeşitlerde bin tane ağırlığı 227.68-242.86 g arasında değişmiştir. Çeşitlerden sprinter 242.86 g ile bin tane ağırlığı en yüksek, Bolero ise $227.68 \mathrm{~g}$ ile bin tane ağırlığı en düşük olduğu bulunmuştur. Bezelye genotiplerinde bin tane ağırlığı 128.39-243.82 g arasında değişim göstermiştir. 
Genotiplerden G18 genotipi 243.82 g ile bin tane ağllı̆̆ en yüksek, G2 genotipi ise $128.39 \mathrm{~g}$ ile bin tane ağırlığı en düşük olduğu bulunmuştur.

Bin tane ağırlığı tohum iriliğine ve dolayısıyla tane verimine göre değișen verimi etkileyen önemli bir verim unsurudur. Özellikle araka tipi bezelye yetiştiriciliğinde bin tane ağırlığının yüksek olması arzu edilen bir özelliktir.

Konuyla ilgili çalıșma yapan araștırmacılardan; Anlarsal ve ark., (2001), 149.8 g, Kazemekas ve ark., (1998), 180 ile 343 g, Gülümser ve ark., (1994), 150.61 ile 310.9 g, Rapan ve ark., (2004), 224.75 ile 323.63 g ve Karayel, (2006), 102.6 ile 363.6 g olarak bildirmişlerdir. Tespit edilen değerlerle çalışmamızda bulduğumuz değerler uyum sağlamaktadır. Bizim çalışmamızdaki genotiplerden G18 bin tane ağırlığı bakımından ticari çeşitlerden daha yüksek değerde bulunmuştur. Bu bakımdan araka tipi bezelye yetiştiriciliğinde tercih edilebilir.

\section{Hasat indeksi}

Denemeye alınan bezelye çeșit ve genotiplerinin hasat indeksine (\%) ait değerler Çizelge 5 de verilmiştir.

Çizelge 5 incelendiğinde ticari çeşitlerde hasat indeksi \% 71-73 arasında değişim göstermiştir. Ticari çeşitlerden Bolero ve Utrilla \% 73 ile hasat indeksi en yüksek, Sprinter çeşiti ise \% 71 ile hasat indeksi en düşük olduğu bulunmuştur. Bezelye genotiplerin de ise hasat indeksi \% 53-73 arasında değișim göstermiştir. Genotiplerden G18 genotipi \% 73 ile hasat indeksi en yüksek, G10 genotipi ise \% 53 ile hasat indeksi en düşük olduğu bulunmuştur.

Konuyla ilgili çalıșma yapan araștırmacılardan; Ceyhan ve Savur, (2011), \% 30.57 ile 38.59, Sümerli ve ark., (2002), \% 33 ile 41 ve Ünver ve Demirci, (2005), \% 38.35 ile 59.69 olarak bildirmişlerdir. Çalışmamızda bulduğumuz değerler tespit edilen değerlerden daha yüksek olduğu görülmektedir. Hasat indeksi tane veriminin toplam biyolojik verime oranının yüzdesidir dolayısıyla genetik faktörler ve çevre koşulları bu değerleri etkilediği sanılmaktadır.

\section{Protein oranı}

Denemeye alınan bezelye çeşit ve genotiplerinin protein oranına (\%) ait değerler Çizelge 5. de verilmiştir. Çizelge 5'de görüldüğü gibi ticari çeşitlerde protein oranı \% 22.96-26.42 arasında değişim göstermiștir. Çeşitlerden Sprinter \% 26.42 ile protein oranı en yüksek, Bolero çeşidi ise \% 22.96 ile protein oranı en düşük olduğu bulunmuştur. Bezelye genotiplerin de ise protein oranı \% 19.86-28.12 arasında değişim göstermiştir. Genotiplerden G12 genotipi \% 28.12 ile protein oranı en yüksek, G13 genotipi ise \% 19.86 ile protein oranı en düşük olduğu bulunmuştur.

Çizelge 5. Bezelye çeşit ve genotiplerinin bitkide tane ağırlığı (g). hasat indeksi (\%) ve protein oranına (\%) ait değerler

\begin{tabular}{ccccc}
\hline Genotip & Kod & B. T. A. (g) & H. I. (\%) & P. O. (\%) \\
\hline G1 & TR2801 & 231.32 & 57 & 25.86 \\
G2 & TR2802 & 128.39 & 60 & 23.58 \\
G3 & TR2803 & 230.27 & 62 & 22.94 \\
G4 & TR2804 & 218.85 & 59.28 & 25.93 \\
G5 & TR2805 & 229.59 & 62 & 24.9 \\
G6 & TR2806 & 226.37 & 64 & 25.49 \\
G7 & TR2807 & 233.84 & 59 & 23.42 \\
G8 & TR2808 & 223.87 & 57.42 & 26.01 \\
G9 & TR2809 & 225.41 & 62 & 25.32 \\
G10 & TR2810 & 190.57 & 53 & 19.92 \\
G11 & TR2811 & 230.79 & 59 & 25.32 \\
G12 & TR2812 & 198.97 & 63 & 28.12 \\
G13 & TR2813 & 234.78 & 58 & 19.86 \\
G14 & TR2814 & 235.37 & 65 & 21.07 \\
G15 & TR2815 & 242.64 & 72 & 20.18 \\
G16 & TR2816 & 243.68 & 71 & 25.39 \\
G17 & TR2817 & 239.89 & 68 & 25.38 \\
G18 & TR2818 & 243.82 & 73 & 27.11 \\
G19 & TR2819 & 238.66 & 66 & 25.79 \\
G20 & TR2820 & 241.25 & 56 & 23.7 \\
G21 & TR2821 & 243.17 & 58 & 25.36 \\
G22 & TR2822 & 226.46 & 57 & 22.73 \\
G23 & TR2823 & 228.25 & 60 & 23.78 \\
G24 & TR2824 & 242.43 & 68 & 21.15 \\
\hline Genotip ort. & & 226.19 & 62 & 24.09 \\
\hline Bolero & & 227.68 & 73 & 22.96 \\
Utrilla & & 234.65 & 73 & 25.32 \\
Sprinter & & 242.86 & 71 & 26.42 \\
\hline Geșit ort. & & 235.06 & 72 & 24.90 \\
\hline Genel ort. & & 230.62 & 67 & 24.49 \\
\hline & & & & \\
\hline
\end{tabular}

Konuyla ilgili çalışma yapan araştırmacılardan; Timurağaoğlu ve ark., (2004), \% 17 ile 23, Seyis, (1994), \% 18.72 ile 24.37, Gülümser ve ark., (1994), \% 19.75 ile 24.01 ve Pekşen ve ark., (2002), \% 26.40 ile 28.10 olarak bildirmişlerdir. Tespit edilen değerlerle denememizde bulduğumuz değerler uyum içerisindedir. Gerek taze tüketim amaciyla gerekse hayvan yemi amacıyla kullanılsın her iki durumda da ham protein oranının yüksek olması bezelye yetiştiriciliğinde arzu edilen en önemli kalite özelliklerinden biridir. Denememizdeki genotiplerden G12 genotipi protein oranı ticari çeşitlerden daha yüksek orandadır. Bu bakımdan yetiştiricilikte tercih edilebilecek özelliktedir.

\section{Sonuç ve Öneriler}

Giresun ilinde yetişen yerel bezelye (Pisum sativum L.) tiplerinin verim ve verim ögelerinin belirlenmesi amacıyla yapılan bu çalışma 2012-2013 üretim sezonunda yürütülmüştür. 
Çalışmada bitki materyeli olarak Giresun ilinin 11 ilçesinden toplanan 24 farklı bezelye genotipi ile 3 tescilli çeşit kullanılmıştır.

Araştırma sonuçlarına göre; bitkide bakla sayısı, ticari çeşitlerde 9.7 ile 17.45 adet/bitki arasında, genotiplerde 9.7 ile 29.85 adet/bitki arasında değişim göstermiştir. Çalışmada ticari çeşitlerin bakla sayısı ortalaması 14.26 adet/bitki olup, bu ortalamayı geçen 16 tane genotip olduğu tespit edilmiştir. Çalıştığımız genotiplerin 10 tanesinin bakla sayıları kullandığımız ticari çeşitlerden bitkide bakla sayısı en yüksek olan Utrilla çeşidini dahi geçmiştir. Bu genotipler; G3, G4, G5, G6, G9, G11, G12, G13, G14, G16 ve G24 genotipleridir. Bu durum yeni çeşitlerin geliştirilmesi için dikkate alınacak en önemli özelliklerden birinin bakla sayısı olması nedeniyle oldukça ümit vericidir. Baklada tane sayısı, ticari çeşitlerde 5.90 ile 7.20 adet/bakla arasında, genotiplerde 4.95 ile 8.15 arasında değişim göstermiștir. Çalışmada ticari çeşitlerin baklada tane sayısı ortalaması 6.75 adet/bakla olup, bu ortalamayı geçen 14 tane genotip olduğu tespit edilmiştir. Çalıştığımız genotiplerin 4 tanesinin tane sayıları kullandığımız ticari çeșitlerden baklada tane sayısı en yüksek olan Utrilla çeşidini dahi geçmiştir. Bu genotipler; G1, G2, G3 ve G4 genotipleridir. Baklada tane sayısı, verimi etkileyen önemli unsurlardan birisidir. Verimli bir yetiştiricilikte bu değerin yüksek olması istenmektedir. Bitkide tane verimi, ticari çeşitlerde 25.35 ile 27.94 g/bitki arasında, genotiplerde 18.45 ile 28.69 g/bitki arasında değişim göstermiştir. Çalışmada ticari çeşitlerin bitki tane verimi ortalaması $26.55 \mathrm{~g} /$ bitki olup, bu ortalamayı geçen 11 tane genotip olduğu tespit edilmiştir. Çalıştığımız genotiplerin 4 tanesinin bitki tane verimi, kullandığımız ticari çeşitlerden bitki tane verimi en yüksek olan Utrilla çeşidini dahi geçmiştir. Bu genotipler; G1, G15, G16 ve G18 genotipleridir. Özellikle tanesi için yetiştirilen tiplerde tane veriminin yüksek olması arzu edilen bir özelliktir. Baklada ortalama kuru tanelerin ağırlığı, ticari çeşitlerde 1.56 ile $1.61 \mathrm{~g}$ arasında, genotiplerde 0.90 ile 2.71 g arasında değișim göstermiştir. Çalıșmada ticari çeşitlerin baklada kuru tane ortalaması $1.59 \mathrm{~g}$ olup, bu ortalamayı geçen 12 tane genotip olduğu tespit edilmiştir. Bu genotiplerden 12 tanesi, kullandığımız ticari çeşitlerden baklada kuru tane ağırlığı en yüksek olan Bolero çeşidini dahi geçmiştir. $\mathrm{Bu}$ genotipler; G1, G2, G7, G8, G10, G15, G17, G18, G20, G21, G22, ve G23 genotipleridir.

Dekara tane verimi, ticari çeşitlerde 126.75 ile 139.7 $\mathrm{kg} / \mathrm{da}$ arasında, genotiplerde 92.25 ile $143.45 \mathrm{~kg} / \mathrm{da}$ arasında değişim göstermiştir. Çalışmada ticari çeșitlerin dekara tane verimi ortalaması $132.7 \mathrm{~kg} / \mathrm{da}$ olup, bu ortalamayı geçen 11 tane genotip olduğu tespit edilmiştir. Çalıştığımız genotiplerin 4 tanesinin dekara tane verimi, kullandığımız ticari çeşitlerden dekara tane verimi en yüksek olan Utrilla çeşidini dahi geçmiştir. Bu genotipler; G1, G15, G16 ve G18 genotipleridir. Dekara biyolojik verim, ticari çeşitlerde 173.63 ile $191.36 \mathrm{~kg} / \mathrm{da}$ arasında, genotiplerde 156.03 ile $250.43 \mathrm{~kg} /$ da arasında değișim göstermiştir. Çalışmada ticari çeşitlerin dekara biyolojik verimi ortalaması $183.4 \mathrm{~kg} / \mathrm{da}$ olup, bu ortalamayı geçen 21 tane genotip olduğu tespit edilmiştir. Çalıştığımız genotiplerden G4, G6, G10 ve G12 hariç tamamının dekara biyolojik verimi, kullandığımız ticari çeşitlerden dekara biyolojik verimi en yüksek olan Utrella çeşidini dahi geçmiştir.

Bin tane ağırlığı, ticari çeşitlerde 227.68 ile 242.86 g arasında, genotiplerde 128.39 ile 243.82 g arasında değişim göstermiştir. Çalışmada ticari çeşitlerin bin tane ağırlı̆̆ı ortalaması 235.6 g olup, bu ortalamayı geçen 8 tane genotip olduğu tespit edilmiştir. Çalıştığımız genotiplerin 3 tanesinin bin tane ağırlığı, kullandığımız ticari çeşitlerden bin tane ağırlığı en yüksek olan Sprinter çeşidini dahi geçmiştir. Bu genotipler; G16, G18, ve G21 genotipleridir. Bin tane ağırlığı tohum iriliğine ve dolayısıyla tane verimine göre değișen verimi etkileyen önemli bir verim unsurudur. Hasat indeksi, ticari çeşitlerde \% 71-73 arasında, genotiplerden \% 53-73 arasında değişim göstermiştir. Çalışmada ticari çeşitlerin hasat indeksi ortalaması \% 72 olup, bu ortalamayı geçen sadece 2 tane genotip olduğu tespit edilmiştir. $\mathrm{Bu}$ genotipler G15 ve G18 genotipleridir. Tanede ham protein oranı, ticari çeşitlerde \% 22.96 ile 26.42 arasında, genotiplerde \% 19.86 ile 28.12 arasında değişim göstermiştir. Çalıșmada ticari çeşitlerin protein oranı ortalaması \% 24.90 olup, bu ortalamayı geçen 13 tane genotip olduğu tespit edilmiştir. Çalıștığımız genotiplerin 2 tanesinin protein oranı kullandığımız ticari çeşitlerden protein oranı en yüksek olan Sprinter çeşidini geçmiştir. Bu genotipler; G12 ve G18 genotipleridir. Gerek taze tüketim amaciyla gerekse hayvan yemi amacıyla kullanılsın her iki durumda da ham protein oranının yüksek olması bezelye yetiştiriciliğinde arzu edilen en önemli kalite özelliklerinden biridir.

Bu çalıșmada özellikle verim yönünden, kullanılan çeșitlerden daha yüksek verim elde edilen G1, G15, G16 ve G18 genotipleri bölge için ümitvar gözükmektedir. 
Ancak kesin bir yargıya varabilmek için araștırmanın birkaç yıl daha devam ettirilmesi uygun olacağı düşünülmektedir.

Sonuç olarak bu araştırmada Giresun ili taranarak yörede yetiştirilen çevre koşullarına uyum sağlamış bezelye populasyonları toplanarak, verim ve verim ögeleri belirlenmeye çalışılmıştır. Toplanan 24 yerel genotipin ileride yapılacak çeşit geliştirme ya da ıslah çalışmaları için kullanılabileceği kanaatine varılmıştır.

\section{Kaynaklar}

Acar Z., Ayan, İ., 2000. Yem bitkileri kültürü. OMÜ Ziraat Fakültesi Yayınları Ders Kitabı No: 2, Samsun, 152.

Açıkgöz, E., Uzun, A., 1997. Yarı yapraklı ve normal yapraklı bezelye (Pisum sativum L.) çeşitlerinden geliştirilen melez hatların bazı tarımsal ve morfolojik özellikleri. OMÜ Ziraat Fakültesi Tarla Bitkileri Bölümü Tarla Bilimleri Derneği Türkiye II. Tarla Bitkileri Kongresi, Samsun, 436-440.

Akçin, A., 1974. Erzurum şartlarında yetiştirilen kuru fasulye çeşitlerinde gübreleme, ekim zamanı ve sıra aralığının tane verimine etkisi ile bu çeşitlerin bazı fenolojik, morfolojik ve teknolojik karakterleri üzerine bir araștırma. Atatürk Üniversitesi Ziraat Fakültesi Yayın No: 157, Erzurum, 112 s..

Akgün. İ., Tosun M., Sağsöz, S., 1998. Bitkisel gen kaynaklarının önemi ve erzurum'un bitkisel gen kaynakları yönünden değerlendirilmesi. Doğu Anadolu Tarım Kongresi Erzurum, 363-372.

Anlarsal, A. E., Yücel C., Özveren D., 2001. Çukurova koşullarında bazı bezelye (Pisum Sativum Ssp. Sativum L. Ve Pisum Sativum Ssp. Avense L.) hatlarının uyumu ve verimlerinin saptanması üzerinde bir araștırma. Ç.Ü.Z.F. Dergisi, 16 (3): 11-20.

Anonim, 2001. Tarımsal değerleri ölçme denemeleri teknik talimatı. Yemeklik tane baklagiller. T.C. Tarım ve Köyişleri Bakanlığı, Koruma ve Kontrol Genel Müdürlüğü, Tohumluk Tescil ve Sertifikasyon Merkezi Müdürlügü, Ankara., 23 s.

Anonim, 2006. Bezelye yetiştiriciliği. Samsun İl Tarım Müdürlügü, S/24, Samsun, 15 s.

Anonim, 2012. Fındık Araştırma Enstitüsü Toprak Analiz Labaratuarl, Giresun, 112 s.

Anonim, 2013. Ordu Meteoroloji İstasyon Müdürlüğü.

Bozoğlu, H., Pekşen, E. ve Gülümser, A., 2004. Sıra aralığı ve potasyum humat uygulamasinın bezelyenin verim ve bazı özelliklerine etkisi. Ankara Üniversitesi Ziraat Fak Tarım Bilimleri Dergisi 10(1): 53-58.
Ceyhan E., Avcı M.A. 2007. Melezleme yöntemi ile elde edilmiş yemeklik bezelye hatlarının verimi ve bazı tarımsal özelliklerinin belirlenmesi. Bildiriler Kitabı, "Tahıllar, Bitki Islahı ve Biyoteknoloji, Yemeklikler Tane Baklagiller" S; 420-423, Türkiye VII. Tarla Bitkileri Kongresi, 25-27 Haziran 2007, Erzurum.

Ceyhan E. ve Önder M. 2001. Farklı zamanlarda ekilen bezelye (Pisum Sativum L.) çeşitlerinde verim ve kalite faktörleri ile bu özelliklerin kolerasyonu ve path analizi. S.Ü. Zir. Fak. Der., 15(26): 139-150.

Ceyhan E., Avcı M.A. ve McPhee K.E. 2005 Konya ekolojik şartlarında kışlık olarak yetiştirilen bezelye genotiplerinin verim ve bazı tarımsal özellikleri. S.Ü. Zir. Fak. Der. 19 (37): 6-12.

Ceyhan E., Mülayim M. 2003. Bezelyede F1 ve F2 generasyonlarında tane verimi ve bazı tarımsal özellikler arasındaki ilişkiler. S.Ü. Zir. Fak. Der., 17 (31): 6873.

Ceyhan, 0., Savur, E., 2011. Melezleme yöntemiyle elde edilen yemeklik bezelye (Pisum sativum L.) hatlarının bazı tarımsal özelliklerinin belirlenmesi. Selçuk Üni. Selçuk Tarım ve Gıda Bilimleri Dergisi 25 (2): 17-23, Konya.

Demirci, G., Ünver, S. 1997. Ankara koşullarında bezelye (Pisum Sativum L.)'de farklı ekim zamanlarının verim ve verim öğelerine etkileri. A.Ü. Fen Bil. Ens., Yüksek Lisans Tezi, s: 50, Ankara, $50 \mathrm{~s}$.

Girgel, Ü. 2006. Kahramanmaraş koşullarında bolero bezelye (Pisum Sativum L.) çeşitinde ekim sıklığının verim ve verim özelliklerine etkisi üzerine bir arastırma. K.S.İ.Ü. Fen Bil. Ens. Yüksek Lisans Tezi, 48 s.

Gülümser A. 1981. Bezelyede azotla gübreleme ve sulamanın verim ve verim unsurları ile tanenin protein oranına etkileri, Atatürk.Üni. Zir.Fak. Tarl.Bit.Böl. Basılmamış Doktora.Tezi, Erzurum, 126 s.

Gülümser A., 1978. Erzurum ekolojik koşullarında yetiştirilen bazı bezelye (Pisum sativum L.) çeşitlerinde bitki sıklığının tane ve sap verimine etkileri üzerinde bir araştırma. Atatürk Üniversitesi Ziraat Fakültesi Dergisi 9(4): 4. 23-36.

Gülümser, A., Seyis, F., Bozoğlu, H., 1994. Samsun ekolojik şartlarında kışlık ve yazlık olarak ekilen bezelye çeşitlerinin konservecilik özellikleri ile tane veriminin tespiti. E.Ü.Z.F. Tarla Bitkileri Bilim Derneği. Tarla Bitkileri Kongresi, İzmir, 87-90.

Kara, K., Ünver, S., 2000. Bezelye (Pisum sativum L.)'de farklı azot dozları ve ekim sıklı̆̆ının verim ve verim öğelerine etkileri. Tarla Bitkileri Merkez Araştırma Enstitüsü (TARM) Dergisi. 8(1-2):36-45. 
Karayel R., 2006. Yerel bezelye genotiplerinin tanımlanmaSı ve bazı agronomik özelliklerinin tespiti. Yüksek lisans tezi, Ondokuz Mayıs Üniversitesi Ziraat Fakültesi Tarla Bitkileri Bölümü, Samsun, 147s.

Karayel R., Bozoğlu H. 2008. Türkiye'nin farklı bölgelerinden toplanan yerel bezelye popülasyonun bazı agronomik özellikleri. O.M.Ü. Zir. Fak. Der. 23 (1): 3238.

Kaya M. 2000. Winner bezelye (Pisum Sativum L.) çeşidinde farklı aşılama yöntemleri, azotlu gübre dozları ile ekim zamanlarının verim ve verim öğelerine etkileri. Ankara Üniv. Fen Bil. Ens. Doktora Tezi, 163 s.

Kazemekas, O., Becius, V., Kazemekiene, B., 1998. Signifinance of productiviy elements of pea for creating new varieties. Biologija (1): 34-36.

Koivisto, J. M., Lane, G. P. F., Davies, W. P., Durand, J. L., Emile, J. C., Huyghe, C. and Lemaire G., 2002. Growth and development of semi-leafless grain and forage peas. Multi function grasslands: quality forages, animal products and landscapes. Proceedings of the 19th General Meeting of the European Grassland Federation, La Rochelle, France, 27-30 May 2002. 430-431.

McPhee, K. E., Muehlbauer F. J., 2002. Improving, the nutritional value of cool seoson food legumes. Journal of Crop Production 5: (1-2): 191-211.

Öz, M., Karasu A., 2010. Bazı bezelye (Pisum sativum L.) çeşitlerinin tohum verimi ve verim komponentlerinin belirlenmesi üzerine bir araștırma. Süleyman Demirel Üni. Zir. Fak. Dergisi 5(1):44-49, Bursa.

Özalp, R., 1993. Farklı pix dozları ve uygulama zamanlarının gökçeada ekolojik şartlarında yetiştirilen araka grubu bezelye çeşitlerinde (Pisum sativum L.) tane verimi, protein miktarı, fenolojik ve morfolojik özellikleri üzerinde bir araştırma. Selçuk Üniv. Fen Bil. Ens. Doktora Tezi, Konya, 100 s.

Özgen. M., M.S. Adak., A. Karagöz., H. Ulukan., 2000. Bitkisel gen kaynaklarının korunma ve kullanımında yeni yaklaşımlar. V. Türkiye Ziraat Mühendisliği Teknik Kongresi. TMMOB Ziraat Mühendisleri Odası, Ankara. 1. Cilt. 259-284.

Pekşen, E., Bozoğlu, H., Peşken, A., Gülümser A., 2002. Determination of the effects of different row spacings on yield and some other properties of pea ( $\mathrm{Pi}$ sum sativum L.) cultivars sown in spring and autumn. 2nd Balkan Symposium on Vegetables and Potatoes 11-15 October 2000, 156 s.
Pekşen, E., Pekşen, A., Bozoğlu, H., Gülümser, A.,2004. Comparison of fresh pod yield and pod related characteristics in pea (Pisum sativum L.) cultivars sown in autumun and spring under Samsun ecological conditions. Turk J Agric For 28 363-370.

Qasim, M., Zubair, M., Wandan, D., 2001. Evaluation of exotic cultivars of pea in Swat valley. Sarhad Journal of Agricultire 17(4): 545-548.

Rapan, I., Jurisic, M., Juric, T., 2004. Response of pea (Pisum sativum subsp. arvense L.) to sowing date, stand and nitrogen fertilization at Vinkovci area. Agriculture Scientific and Professional Review. 10 (1): 2530 .

SPSS, 2006. SPSS Base 15.0 User's Guide, SPSS Inc., Chicago, USA.

Salk, A., 1971. Yerli ve yabancı orijinli bezelye çeşitlerinin morfolojik ve pomolojik vasıfları ile soğuğa mukavemetleri üzerine araștırmalar (Doktora Tezi). E. Ü. Fen. Bil. Ens. Bornova. İzmir.

Seyis, F., 1994. Samsun ekolojik şartlarında yazlık olarak ekilen bezelye çeşitlerinin tane verimi ile bazı önemli özellikleri ve bunlar arasındaki ilişkiler üzerine bir araştırma. Yüksek Lisans Tezi, Ondokuz Mayıs Üniversitesi Fen Bilimleri Enstitüsü, Samsun. $75 \mathrm{~s}$.

Sincik, M., Azkan, N., Karasu A., 1997. Bezelyede farklı ekim zamanlarının verim ve verim öğeleri üzerine etkisi. Uludağ Üniversitesi Ziraat Fakültesi Dergisi, 13: 121-131.

Sürmeli M, Gül İ ve Yılmaz Y, 2002. Diyarbakır Ekolojik Şartlarında Yem Bezelyesi Hatlarının Verim ve Verim Öğelerinin Belirlenmesi. Güneydoğu Anadolu Tarımsal Araştırma Enst. Md. Gelişme Raporları Diyarbakır, $78 \mathrm{~s}$.

Timurağaoğlu, K. A., Genç, A., Altınok, S., 2004. Ankara koşullarında yem bezelyesi hatlarında yem ve tane verimleri. Ankara Üniversitesi Ziraat Fakültesi Tarım Bilimleri Dergisi, 10 (4) 457-461.

Ünver, S., Demirci, G. 2005. Ankara koşullarında Bezelye'de (Pisum sativum L.) farklı ekim zamanlarının verim ve verim öğelerine etkileri. Anadolu J. of AARI 15 (1): 49-60 MARA.

Vural, H., 1971. önemli yazlık sebze çeşitlerinin tohum verimleri üzerinde araștırmalar. Ege Üniv. Ziraat Fak. Dergisi. 8(2): 175-206. 